\title{
Changes in quality attributes of sand smelt (Atherina hepsetus) fish burger and finger during frozen storage.
}

\author{
Adel A. El-Lahamy ${ }^{1 *}$, Khalil I. Khalii ${ }^{2}$, Shaban A. El-Sherif ${ }^{1}$, Awad A. Mahmud ${ }^{2}$ \\ ${ }^{1}$ National Institute of Oceanography and Fisheries, Fish Processing Technology Laboratory, Cairo, Egypt. \\ ${ }^{2}$ Food Science and Technology Department, Faculty of Agriculture, Fayoum University, Fayoum.
}

\begin{abstract}
The present investigation has been carried out with the objectives study the effect of frozen storage on quality attributes of fish burger and fingers were made from sand smelt (bassaria) (Atherina hepsetus) with substitution levels from soybean flour and minced potato. Sand smelt has found in Qarun Lake by unaccepted from consumers. The physicochemical and microbiological analysis was carried on raw products immediately after processing and during frozen storage. Total Volatile Basic Nitrogen (TVBN), Trimethylamine (TMA), Thiobarbituric Acid (TBA) and pH values of sand smelt fish products showed significant increase during frozen storage for 3 months except $\mathbf{p H}$ value. Quality attributes parameters values of control samples were higher than those with substitution levels by soybean flour and minced potato. Sand smelt fish burger and finger made from sand smelt fish maintained on their good quality parameters until end of storage period.
\end{abstract}

Keywords: Fish products, Preservation technique, Low temperature storage, Processed fish.

Accepted on October 07, 2018

\section{Introduction}

Fish and fishery products have been recognized as very important sources for human nutrition. Fishes are characterized by their high contents of high quality and easily digestible protein and essential amino acids. Moreover, they are low in the saturated fatty acids and contain considerable amounts of the unsaturated fatty acids, especially omega-3 fatty acids, which are regarded as oxidation preventive compounds. The oil-soluble vitamins are known to be rich in fish. Also, fish is a good source of several minerals particularly fluorine and iodine, which are needed for the development of strong teeth and the prevention of goiter in man [1,2]. In 2012, aquaculture provided around half $(50.3 \%)$ of all fish supplies destined for direct human food consumption. However, fish has been estimated to account for only $6.5 \%$ of the global protein consumption (and about $14 \%$ of total fish and animal protein supply). Fish provides about $60 \%$ of palatable fish is utilized by end-users while the remaining is either converted or lost. Post-harvest loss due to decay is estimated to be between 10-12 million tons annually which accounts for about $10 \%$ of global capture and culture fish [3-6]. Sand smelt (Atherina boyeri) is a common species in the Mediterranean Sea and has shown distribution from northeast Atlantic to northwest coast of Scotland. Also, this species lives in the Black Sea, Aegean Sea, Marmara Sea, Aral and Caspian Sea [7]. In recent years, increases of the civilization and changes in the socioeconomic factors such as more women in the work force, have resulted in increased consumers' preference for ready-to-eat foods (heat and eat). Thus, efforts have been made to improve the quality and stability of these foods and those made from fish are becoming very popular, such as fish minced, burgers, fingers, marinated products, etc. [8-10]. Total Volatile Basic Nitrogen (TVBN), Trimethylamin (TMAN) and
Thiobarbeturic Acid (TBA) are good index to determine the freshness and quality of fishes and their products. The objective of the investigation are summarized in following up the storage changes occurred in chemical quality parameters to assess the storage stability of sand smelt fish products during frozen storage.

\section{Materials and Methods}

\section{Fish}

Fresh sand smelt (bassaria) fish (Atherina hepsstia) was obtained from Qarun Lake at Fayom Governorate, Egypt during April, 2017. About $25 \mathrm{~kg}$ of fish were transported in ice to the laboratory of Fish Research Station (at Shakshouk, Fayoum), National Institute of Oceanography and Fisheries.

\section{Filling materials}

Soybean Flour (SF) and Minced Boiled Potatoes (MBP) were used as filling materials in the processing of fish products. SF was obtained from Food Technology Research Institute, Agriculture Research Center at Giza Governorate, Egypt. MBP was prepared by boiling potatoes for $15 \mathrm{~min}$, then peeled and minced.

\section{Ingredients}

The ingredients included sunflower oil, starch, wheat flour, sugar, salt, onion, garlic, spices, and other additives were obtained from the local market.

\section{Preparation of fish}

On arrival at the laboratory, fish was beheaded, gutted and washed gently with tap water. The edible portion of fish was soaked in $1 \%$ salt solution contained $0.5 \%$ acetic acid for 5 
min to remove the fishery odor and taste, then drained off and minced using an electric meat mincer (Braun plus 1300). A portion of the minced fish was used in the chemical analysis and the microbial examination of the raw material (sand smelt fish). The remaining quantity was divided into two portions, kept to process fish products of burger and finger.

\section{Fish burger formulation and processing}

Control fish burger (no filling material) was composed of $75 \mathrm{~g}$ of minced fish and $25 \mathrm{~g}$ of the ingredients mixture for 100 $\mathrm{g}$ batter as shown in Table 2 which indicates the recipe of sand smelt burger as mentioned by [11]. The experimental burgers were formulated by using SF and MBP as filling materials. Each of the two filling materials was used at levels of 10,15 and $20 \%$ of weight of the minced fish used. The experimental formulated samples were made by replacing the minced fish with the filling material at the desired level as illustrated in Table 1. All the formulations were needed by hand until homogenous dough was obtained. Portions of $50 \mathrm{~g}$ were shaped $(8.5 \mathrm{~cm}$ diameter and $1.0 \mathrm{~cm}$ thickness) by manually operated forming machine (NOAW-Affetacrane, Italy). Burger samples were packaged in polyethylene bags and stored at $-18^{\circ} \mathrm{C}$ until required for analysis.

\section{Fish fingers formulation and processing}

Fish fingers were prepared as described by [8] and [12] Control fish fingers (without filling material) were composed of $93.5 \mathrm{~g}$ of minced sand smelt fish and $6.5 \mathrm{~g}$ of the ingredients mixture as shown in Table 1 . The experimental fingers were formulated by using the filling materials i.e. SF and MBP at levels of 10,15 and $20 \%$ of the minced fish as described in burger formulation. The formulated samples were made by replacing the minced fish with the filling materials at the tested levels (Table 2). The minced fish was mixed with the ingredients and the mixture was homogenized until smooth

Table 1. Substitution levels of the filling materials (SF and MBP) used in the preparation of sand smelt fish burger and fingers

Soybean flour, MBP: Minced boiled potato

\begin{tabular}{|c|c|c|c|c|}
\hline \multicolumn{2}{|c|}{ Fish burger } & \multicolumn{2}{c|}{ Fish fingers } & Substitution Level \\
\hline $\begin{array}{c}\text { Minced fish } \\
\text { (g) }\end{array}$ & (SF) or (MBP)(g) & $\begin{array}{c}\text { Minced fish } \\
\text { (g) }\end{array}$ & $\begin{array}{c}\text { (SF) or } \\
\text { (MBP) (g) }\end{array}$ & \begin{tabular}{c} 
(M) \\
\hline 75.00
\end{tabular} \\
\hline 67.50 & - & 93.50 & - & 0 \\
\hline 63.75 & 7.50 & 84.15 & 9.35 & 10 \\
\hline 60.00 & 11.25 & 79.47 & 14.03 & 15 \\
\hline
\end{tabular}

Table 2. Recipes of sand smelt fish burger and fingers.

*Spices mixture composed of $32 \%$ black pepper, $22.5 \%$ coriander, $15 \%$ cumin, 10\% cardamom, 9\% red pepper, $7.5 \%$ cubeb and $4 \%$ clove

\begin{tabular}{|l|c|l|c|}
\hline \multicolumn{2}{|c|}{ Fish burger } & \multicolumn{2}{c|}{ Fish fingers } \\
\hline Ingredients & $\%$ & Ingredients & $\%$ \\
\hline Fish mince & 75.00 & Fish mince & 93.50 \\
\hline Vegetable oil & 9.00 & Salt & 1.50 \\
\hline Starch & 8.00 & Sugar & 1.00 \\
\hline Salt & 2.30 & Wheat flour & 3.00 \\
\hline Sodium bicarbonate & 0.40 & Cumin & 0.24 \\
\hline Onion & 2.50 & Onion & 0.24 \\
\hline Garlic & 0.50 & Garlic powder & 0.24 \\
\hline Polyphosphate & 0.30 & Black pepper & 0.24 \\
\hline *Spices mixture & 2.00 & Thyme & 0.04 \\
\hline
\end{tabular}

dough was obtained. The dough was shaped into fingers and frozen at $-18^{\circ} \mathrm{C}$ for $2 \mathrm{~h}$ before battering. The frozen fish fingers were rapidly coated with batter solution ( 3 parts of water plus 2 parts contained $94 \%$ maize flour, $2 \%$ skim milk, $2 \%$ egg yolk and $2 \%$ salt) and then they were rubbed with ground crumb.

\section{Storage stability}

Storage studies were made to investigate the storage stability of sand smelt fish products (burgers and fingers) during frozen storage. Based on the data collected from the sensory evaluation for the different formulation of burgers and fingers, it was selected the more suitable levels of filling materials (SF and MBP) to carryout storage studies. The selected formulated samples along with the control samples of burgers and fingers were packed in polyethylene bags and stored in deep freezer at $-18^{\circ} \mathrm{C}$ for three months. Samples were withdrawn periodically at intervals of 15 days for analysis.

\section{Analytical methods}

Total volatile basic-nitrogen was determined by macrodistillation method as described by [13] and the results obtained were expressed as mg TVB-N/100 $\mathrm{g}$ fresh sample. TMA-N was determined as described in [14] and the results were expressed as mg TMA/100 g dry sample. Malonaldehyde content was calorimetrically determined as described by [13] and the results were expressed as $\mathrm{mg}$ malonaldhye $/ \mathrm{kg}$ of sample. The $\mathrm{pH}$ value was measured according to [14] as the follows: $10 \mathrm{~g}$ of the minced sample were homogenized with $100 \mathrm{ml}$ of distilled water and the mixture was filtered by using filter paper. The $\mathrm{pH}$ value of the filtrate was measured using $\mathrm{pH}$ meter with combined electrode.

\section{Statistical analysis}

The statistical analysis of the results obtained was carried out according to SPSS version 16 software program 2007. Means and Standard Error (SE) measure at 5\% level of significant.

\section{Results and Discussion}

\section{Chemical quality parameters and $\mathrm{pH}$}

Total volatile basic nitrogen, trimethylamine nitrogen, thiobarbeturic acid as well as $\mathrm{pH}$ values are widely used as chemical quality parameters to assess the quality and storage stability of fish and fishery products.

\section{Total volatile basic nitrogen (TVB-N)}

TVB-N contents of sands melt fish products (burgers and fingers) were determined periodically at intervals of 15 days during frozen storage for 90 days. The results obtained are shown in Table 3. It was observed that the values of TVB-N showed wavy progress for both fish burgers and fingers samples. The initial values of TVB-N for control burger sample and those formulated by the incorporation of $15 \% \mathrm{SF}$ and $15 \% \mathrm{MBP}$ were determined by $17.11,14.52$ and $12.00 \mathrm{mg} / 100 \mathrm{~g}$ respectively. After 30 days of frozen storage, these values increased up to $18.20,16.50$ and $13.53 \mathrm{mg} / 100 \mathrm{~g}$ (dry weight basis) respectively then decreased down to $17.85,14.17$ and $13.18 \mathrm{mg} / 100 \mathrm{~g}$ respectively. At the end of 90 days of frozen storage, TVB-N 
Table 3. Changes in TVB- $N$ content $(\mathrm{mg} / 100 \mathrm{~g})$ of sand smelt fish products during frozen storage at $-18^{\circ} \mathrm{C}$. Data are presented as mean $\pm S E$ of 3 replicates. SE: standard error. Significant difference at $P<0.05$. SF: Soybean flour. MBP: Minced boiled potato

\begin{tabular}{|c|c|c|c|c|c|c|}
\hline \multirow[b]{2}{*}{ Storage period (day) } & \multicolumn{3}{|c|}{ Fish Burger } & \multicolumn{3}{|c|}{ Fish Finger } \\
\hline & Control & $\begin{array}{c}\text { SF } \\
(15 \%)\end{array}$ & $\begin{array}{c}\text { MBP } \\
(15 \%)\end{array}$ & Control & $\begin{array}{c}\text { SF } \\
(20 \%)\end{array}$ & $\begin{array}{c}\text { MBP } \\
(15 \%)\end{array}$ \\
\hline 0 & $17.11 \pm 0.063$ & $14.52 \pm 0.184$ & $12.60 \pm 0.202$ & $18.55 \pm 0.144$ & $15.81 \pm 0.121$ & $13.06 \pm 0.034$ \\
\hline 15 & $18.00 \pm 0.577$ & $15.60 \pm 0.785$ & $13.02 \pm 0.242$ & $19.45 \pm 0.259$ & $16.01 \pm 0.118$ & $13.46 \pm 0.265$ \\
\hline 30 & $18.20 \pm 0.115$ & $16.50 \pm 0.288$ & $13.53 \pm 0.115$ & $19.67 \pm 0.057$ & $16.69 \pm 0.178$ & $13.68 \pm 0.184$ \\
\hline 45 & $18.05 \pm 0.202$ & $14.50 \pm 0.230$ & $13.23 \pm 0.132$ & $19.06 \pm 0.034$ & $16.17 \pm 0.098$ & $13.09 \pm 0.051$ \\
\hline 60 & $17.85 \pm 0.144$ & $14.17 \pm 0.098$ & $13.18 \pm 0.103$ & $18.95 \pm 0.144$ & $16.03 \pm 0.240$ & $12.36 \pm 0.207$ \\
\hline 75 & $18.32 \pm 0.184$ & $15.22 \pm 0.127$ & $14.52 \pm 0.300$ & $20.46 \pm 0.265$ & $17.59 \pm 0.236$ & $13.69 \pm 0.178$ \\
\hline 90 & $19.50 \pm 0.288$ & $16.63 \pm 0.213$ & $14.72 \pm 0.127$ & $21.87 \pm 0.213$ & $17.80 \pm 0.173$ & $15.22 \pm 0.127$ \\
\hline Sig. & .002 & .001 & .000 & .000 & .000 & .000 \\
\hline
\end{tabular}

Table 4. Changes in TMA-N content ( $\mathrm{mg} / 100 \mathrm{~g}$ ) of sand smelt fish products during frozen storage at $-18^{\circ} \mathrm{C}$.

Data are presented as mean \pm SE of 3 replicates. SE: standard error. Significant difference at P<0.05. SF: Soybean flour. MBP: Minced boiled potato

\begin{tabular}{|c|c|c|c|c|c|c|}
\hline \multirow{2}{*}{$\begin{array}{l}\text { Storage period } \\
\text { (day) }\end{array}$} & \multicolumn{3}{|c|}{ Fish Burger } & \multicolumn{3}{|c|}{ Fish Finger } \\
\hline & Control & $\begin{array}{c}\text { SF } \\
(15 \%)\end{array}$ & $\begin{array}{l}\text { MBP } \\
(15 \%)\end{array}$ & Control & $\begin{array}{c}\text { SF } \\
(20 \%)\end{array}$ & $\begin{array}{l}\text { MBP } \\
(15 \%)\end{array}$ \\
\hline 0 & $1.30 \pm .028$ & $1.05 \pm 0.034$ & $0.81 \pm 0.034$ & $2.23 \pm 0.132$ & $2.10 \pm 0.057$ & $0.90 \pm 0.057$ \\
\hline 15 & $1.53 \pm .075$ & $1.2 \pm 8.161$ & $0.83 \pm 0.075$ & $2.48 \pm 0.161$ & $2.18 \pm 0.103$ & $1.10 \pm 0.051$ \\
\hline 30 & $1.70 \pm .173$ & $1.51 \pm 0.063$ & $0.89 \pm 0.051$ & $2.60 \pm 0.115$ & $2.25 \pm 0.144$ & $1.23 \pm 0.132$ \\
\hline 45 & $1.86 \pm .092$ & $1.76 \pm 0.150$ & $0.94 \pm 0.080$ & $2.66 \pm 0.086$ & $2.36 \pm 0.115$ & $1.45 \pm 0.028$ \\
\hline 60 & $2.00 \pm .115$ & $1.77 \pm 0.155$ & $1.12 \pm 0.069$ & $2.75 \pm 0.086$ & $2.32 \pm 0.184$ & $1.50 \pm 0.144$ \\
\hline 75 & $2.10 \pm .057$ & $1.83 \pm 0.190$ & $1.35 \pm 0.202$ & $2.80 \pm 0.144$ & $2.55 \pm 0.086$ & $1.67 \pm 0.118$ \\
\hline 90 & $2.17 \pm .086$ & $1.89 \pm 0.051$ & $1.62 \pm 0.069$ & $2.87 \pm 0.098$ & $2.76 \pm 0.034$ & $1.95 \pm 0.086$ \\
\hline Sig. & .000 & .003 & .000 & .033 & .016 & .0000 \\
\hline
\end{tabular}

values in control, $15 \% \mathrm{SF}$ and $15 \% \mathrm{MBP}$ burger samples became $19.50,16.63$ and $14.72 \mathrm{mg} / 100 \mathrm{~g}$ (wet weight basis) respectively.

Fish finger samples showed the same behavior regarding the changes in their contents of TVB-N during frozen storage (Table 3). The initial values of TVB-N in control finger sample and those formulated with adding 20\% SF and 15\% MBP were $18.55,15.81$ and $13.06 \mathrm{mg} / 100 \mathrm{~g}$ (wet weight basis) respectively. These values irregularly changed during frozen storage reaching to $21.87,17.80$ and $15.22 \mathrm{mg} / 100 \mathrm{~g}$ at the end of 90 days storage respectively.

The fluctuation of TVBN levels found in sands melt fish products had been reported for some fish products during storage under similar conditions $[15,16]$. Increasing TVB-N values during storage was attributed to the activity of microbial and endogenous protolytic enzymes which breakdown proteins to volatile nitrogenous compounds $[17,18]$. Meanwhile, the elimination of dissolved volatile constituents through drip could be caused decreasing of TVB-N values during frozen storage $[19,20]$.

TVB-N is one of spoilage parameters in fish and fish products. In the study made by [21] it was suggested the limit values of TVBN as very good until $25 \mathrm{mg} / 100 \mathrm{~g}$, good until $30 \mathrm{mg} / 100 \mathrm{~g}$, marketable until $35 \mathrm{mg} / 100 \mathrm{mg}$ and spoilt more than $35 \mathrm{mg} / 100$ g. In the present study, TVBN contents of sands melt fish products ranged between the lowest values determined by $12.60 \mathrm{mg} / 100 \mathrm{~g}$ in the $15 \% \mathrm{MBP}$ burger sample at zero day storage to the highest value of $21.87 \mathrm{mg} / 100 \mathrm{~g}$ for control fingers sample stored for 90 days. These findings indicated the good quality of sands melt fish products even after 90 days of frozen storage.

\section{Trimethylamin nitrogen (TMA-N)}

Data presented in Table 4 show the changes in TMA-N contents of sand smelt fish products during frozen storage at $-18{ }^{\circ} \mathrm{C}$ for 90 days. The results indicated that burger and finger samples contents of TMA-N gradually increased as the storage period extended. The initial values of TMA-N contents of control burger sample and 15\% SF and $15 \%$ MBP formulated samples were determined by $1.30,1.05$ and $0.81 \mathrm{mg} / 100 \mathrm{~g}$ respectively. These initial values gradually increased up to $2.17,1.89$ and $1.62 \mathrm{mg} / 100 \mathrm{~g}$ respectively at the end of 90 days of frozen storage. Similarly, changed in TMA-N contents of sand smelt fingers followed the sample trend. The initial levels of TMA-N in control finger sample and the $20 \% \mathrm{SF}$ and $15 \% \mathrm{MBP}$ formulated samples were 2.23 , 2.10 and $0.90 \mathrm{mg} / 100 \mathrm{~g}$ respectively. These values indicated that TMAN contents of finger samples were slightly higher than their levels in burger samples. During storage, these values gradually increased up to $2.87,2.76$ and $1.95 \mathrm{mg} / 100$ $\mathrm{g}$ after 90 days storage at $-18^{\circ} \mathrm{C}$ respectively. Such increments in TMA-N during storage may be due to the conversion of TMAO into TMA by the endogenous and/or bacterial enzyme TMAase. TMA is used as an index of freshness and quality of fish. It had been reported [22] that perfectly fresh fish had $3.37 \mathrm{mg} / 100 \mathrm{~g}$ TMA-N; good grade fish showed a level of $3.79-5.90 \mathrm{mg} / 100 \mathrm{~g}$ and fair fish had 12.56-16.02 mg/100 g. Accordingly, values of TMA-N found in the present study indicated the good quality of sand smelt fish burgers and fingers even after 90 days of frozen storage.

\section{Thiobarbituric acid (TBA)}

TBA is widely used as an indicator of the degree of lipid 
Citation: El-Lahamy AA, Khalil KI, El-Sherif SA, et al. Changes in quality attributes of sand smelt (Atherina hepsetus) fish burger and finger during frozen storage. J Fish Res. 2018;2(2):6-11.

oxidation. In the present study, TBA values for sand smelt fish products during frozen storage were determined as malonaldhyde $(\mathrm{mg} / \mathrm{kg})$ and data obtained are presented in Table 5. Initially, TBA values of control, $15 \% \mathrm{SF}$ and $15 \% \mathrm{MBP}$ burger samples were $0.70,0.65$ and $0.61 \mathrm{mg} \mathrm{MDA} / \mathrm{kg}$ respectively. During frozen storage of burger samples, TBA values showed a gradual increase. At the end of storage period ( 90 days), TBA values of control, $15 \% \mathrm{SF}$ and $15 \%$ MBP increased up to 1.42 , 1.30 and $0.96 \mathrm{mg} \mathrm{MDA} / \mathrm{kg}$ respectively. Similar observations were also found in the changes of TBA values of sand smelt fish finger samples during frozen storage. The results given in Table 5 indicated that the initial values of TBA in control, $20 \%$ $\mathrm{SF}$ and $15 \%$ MBP increased from $0.59,0.53$ and $0.36 \mathrm{mg}$ MDA/ $\mathrm{kg}$ respectively before storage to $0.77,0.69$ and $0.56 \mathrm{mg} \mathrm{MDA} /$ $\mathrm{kg}$ after 90 days storage respectively. The increasing of TBA value during frozen storage of sand smelt fish products has been demonstrated for similar products made from other fish types $[12,23,24]$.

TBA determination is an important quality index, indicating fat oxidation .The TBA value should be less than $3 \mathrm{mg}$ MDA/ $\mathrm{kg}$ in perfect quality material and should not be more than $5 \mathrm{mg}$ $\mathrm{MDA} / \mathrm{kg}$ in good quality material and consumption limits were from 7 to $8 \mathrm{mg}$ MDA/kg [25]. In the present study, the highest value of TBA was determined as $1.42 \mathrm{mg} \mathrm{MDA} / \mathrm{kg}$ for control burger sample indicating the good quality of the different samples of sand smelt fish products even after 3 months of frozen storage.

\section{pH value}

$\mathrm{pH}$ value was measured in fish products made from sand smelt fish during frozen storage and results obtained are presented in Table 6. Initially, it was observed that $\mathrm{pH}$ values of finger samples were higher than those of burger samples. As shown in Table 6, the initial $\mathrm{pH}$ values for burger and fingers samples ranged between 6.45-6.58 and 6.64-6.70 respectively. These variations may be due to the differences between the ingredients used in the preparation of fish burgers and fingers [26] reported similar observations. The changes in $\mathrm{pH}$ value during frozen storage of sand smelt fish products showed gradual increase as the storage period extended. The initial $\mathrm{pH}$ values of control, $15 \% \mathrm{SF}$ and $15 \%$ MBP burger samples increased from $6.48,6.58$ and 6.45 to $6.80,6.68$ and 6.60 after 3 months storage at $-18{ }^{\circ} \mathrm{C}$. Similarly, $\mathrm{pH}$ values of control, $20 \% \mathrm{SF}$ and $15 \%$ MBP fingers samples gradually increased from $6.70,6.69$ and 6.79 to $7.03,6.95$ and 6.79 at the end of 90 days storage. Several studies showed inconsistency results regarding increasing or decreasing $\mathrm{pH}$ value in various fish species during storage [20, 25, 27-29]. The increase in the $\mathrm{pH}$ value during storage could be due to the enzymatic degradation of fish muscle components [30]. Rising $\mathrm{pH}$ during storage also may be due to formation of dimethyl amine from trimethylamine oxide [31]. $\mathrm{pH}$ values between 6.8-7.0 were proposed as acceptance limit of fish, and values above 7 were considered to be spoiled [32,33].

\section{Conclusion}

Sand smelt fish products (Burger and Fingers) maintained a good quality during frozen storage at $-18^{\circ} \mathrm{C}$ for 3 months. Utilization of substitution levels from soybean flour and mince potato improved the quality attributes of fish burger and fish finger made from sand smelt fish. Sand smelt fish can be used to produce high quality fish products on as large scale manufacturing.

Table 5. Changes in TBA value ( $m g \mathrm{MDA} / \mathrm{Kg}$ ) of sand smelt fish products during frozen storage at $-18^{\circ} \mathrm{C}$.

Data are presented as mean \pm SE of 3 replicates. SE: standard error. Significant difference at $P<0.05 . S F$ : Soybean flour. MBP: Minced boiled potato

\begin{tabular}{|c|c|c|c|c|c|c|}
\hline \multirow{2}{*}{$\begin{array}{l}\text { Storage period } \\
\text { (day) }\end{array}$} & \multicolumn{3}{|c|}{ Fish Burger } & \multicolumn{3}{|c|}{ Fish Finger } \\
\hline & Control & $\begin{array}{c}\text { SF } \\
(15 \%)\end{array}$ & $\begin{array}{l}\text { MBP } \\
(15 \%)\end{array}$ & Control & $\begin{array}{c}\text { SF } \\
(20 \%)\end{array}$ & $\begin{array}{l}\text { MBP } \\
(15 \%)\end{array}$ \\
\hline 0 & $0.70 \pm 0.034$ & $0.65 \pm 0.028$ & $0.61 \pm 0.023$ & $0.59 \pm 0.011$ & $0.53 \pm 0.017$ & $0.36 \pm 0.034$ \\
\hline 15 & $0.81 \pm 0.023$ & $0.71 \pm 0.023$ & $0.67 \pm 0.028$ & $0.61 \pm 0.017$ & $0.55 \pm 0.028$ & $0.40 \pm 0.011$ \\
\hline 30 & $0.90 \pm 0.028$ & $0.77 \pm 0.040$ & $0.68 \pm 0.023$ & $0.63 \pm 0.017$ & $0.59 \pm 0.023$ & $0.40 \pm 0.017$ \\
\hline 45 & $1.15 \pm 0.086$ & $1.02 \pm 0.023$ & $0.71 \pm 0.028$ & $0.70 \pm 0.046$ & $0.59 \pm 0.034$ & $0.43 \pm 0.023$ \\
\hline 60 & $1.16 \pm 0.080$ & $1.16 \pm 0.092$ & $0.75 \pm 0.028$ & $0.70 \pm 0.057$ & $0.62 \pm 0.040$ & $0.48 \pm 0.034$ \\
\hline 75 & $1.25 \pm 0.115$ & $1.24 \pm 0.057$ & $0.92 \pm 0.069$ & $0.73 \pm 0.017$ & $0.67 \pm 0.023$ & $0.51 \pm 0.017$ \\
\hline 90 & $1.42 \pm 0.069$ & $1.30 \pm 0.132$ & $0.96 \pm 0.034$ & $0.77 \pm 0.040$ & $0.69 \pm 0.040$ & $0.56 \pm 0.034$ \\
\hline Sig. & .000 & .000 & .000 & .018 & .022 & .001 \\
\hline
\end{tabular}

Table 6. Changes in $\mathrm{pH}$ value ( $\mathrm{mg} \mathrm{MDA} / \mathrm{Kg}$ ) of sand smelt fish products during frozen storage at $-18^{\circ} \mathrm{C}$.

Data are presented as mean $\pm S E$ of 3 replicates. SE: standard error. Significant difference at $P<0.05$. SF: Soybean flour. MBP: Minced boiled potato

\begin{tabular}{|c|c|c|c|c|c|c|}
\hline \multirow{2}{*}{$\begin{array}{l}\text { Storage period } \\
\text { (day) }\end{array}$} & \multicolumn{3}{|c|}{ Fish Burger } & \multicolumn{3}{|c|}{ Fish Finger } \\
\hline & Control & $\begin{array}{c}\mathrm{SF} \\
(15 \%)\end{array}$ & $\begin{array}{c}\text { MBP } \\
(15 \%)\end{array}$ & Control & $\begin{array}{c}\text { SF } \\
(20 \%)\end{array}$ & $\begin{array}{c}\text { MBP } \\
(15 \%)\end{array}$ \\
\hline 0 & $6.48 \pm 0.173$ & $6.58 \pm 0.046$ & $6.45 \pm 0.028$ & $6.70 \pm 0.115$ & $6.69 \pm 0.051$ & $6.64 \pm 0.011$ \\
\hline 15 & $6.57 \pm 0.057$ & $6.58 \pm 0.046$ & $6.48 \pm 0.034$ & $6.79 \pm 0.109$ & $6.77 \pm 0.115$ & $6.65 \pm 0.086$ \\
\hline 30 & $6.60 \pm 0.173$ & $6.60 \pm 0.115$ & $6.49 \pm 0.167$ & $6.8 \pm 0.144$ & $6.79 \pm 0.051$ & $6.70 \pm 0.115$ \\
\hline 45 & $6.62 \pm 0.098$ & $6.60 \pm 0.086$ & $6.55 \pm 0.086$ & $6.86 \pm 0.057$ & $6.79 \pm 0.115$ & $6.70 \pm 0.144$ \\
\hline 60 & $6.65 \pm 0.115$ & $6.60 \pm 0.069$ & $6.56 \pm 0.178$ & $6.86 \pm 0.173$ & $6.80 \pm 0.069$ & $6.72 \pm 0.069$ \\
\hline 75 & $6.68 \pm 0.046$ & $6.63 \pm 0.103$ & $6.58 \pm 0.057$ & $6.86 \pm 0.092$ & $6.83 \pm 0.106$ & $6.75 \pm 0.086$ \\
\hline 90 & $6.80 \pm 0.115$ & $6.68 \pm 0.057$ & $6.60 \pm 0.086$ & $7.03 \pm 0.075$ & $6.95 \pm 0.086$ & $6.79 \pm 0.051$ \\
\hline Sig. & .672 & .973 & .983 & .614 & .607 & .902 \\
\hline
\end{tabular}




\section{References}

1. Potter NN. Food Science $4^{\text {th }}$ Ed. Westport: AVI Pub. Comp. 1986.

2. Gulyavuz H, Unlusayın M. Fish Processing Technology. Turkey. 1999.

3. Domingo JL, Bocio A, Falco G, et al. Benefits and risks of fish consumption: Part I. A quantitative analysis of the intake of omega-3 fatty acids and chemical contaminants. Toxicol. 2007;230:219-26.

4. Ruckes E. World fish trade, demand, forecasts and regulatory framework. The Expert Consultation on International Fish Trade. Brazil. 2003.

5. Ahmed AA. Postharvest losses of fish in developing countries. J Nutr Health. 2008;19:273-87.

6. FAO. Post-harvest changes in fish. Fisheries and Aquaculture Department. Food and Agriculture Organization of the United Nations. 2014.

7. Altun O. Morphological Variations Observed in Sand Smelt (Atherina boyeri Risso, 1810) Populations Trend. J Zool. 1999;23(3):911-18.

8. Çakli S, Taskaya L, Kisla D, et al. Production and quality of fish finger from different fish species. Eur Food Res Technol. 2005;220:526-30.

9. Izci L. Utilization and quality of fish fingers from Prussian Carp (Carassius gibelio Bloch, 1782). Pak Vet J. 2010;30(4):207-10.

10. El-SherifSA. Evaluation offish cakes processed from bassaria fish (Atherina hepsetia) J Agric Sci. 2007;32(3):2071-83.

11. Chandrasckhar TC, Mohite RR. Effect of fat coated sorbic acid (ECSA) and the shelf life of fish sausage stored at $10^{\circ} \mathrm{C}$ and ambient temperature. J Sea Food Export. 1978;10(11):19-23.

12. Tokur B, Ozkutuk S, Atici E, et al. Chemical and sensory quality changes of fish fingers made from mirror carp (Cyprinus carpio L., 1758) during frozen storage $\left(-18^{\circ} \mathrm{C}\right)$. Food Chem. 2006;99:335-41.

13. Pearson D. The chemical Analysis of Food .Churchill, New York, London. 1991;374-410.

14. A.O.A.C. Association of official analytical chemists. Official methods of analysis. $19^{\text {th }}$ edition. USA. 2012.

15. Kilina B, Cakli S, Kisla D. Quality changes of Sardine (Sardina pilchardus W., 1792) during frozen storage. E.U. Journal of Fisheries \& Aquatic Sciences. 2003;20:139-46.

16. Izci L, Sengul B, Ali G. Production of fish chips from sand smelt (Atherina boyeri, RISSO 1810) and Determination of some quality changes. Iran J Fish Sci. 2011;10(2):230-41.

17. Chomnawang C, Nantachai K, Yongsawatdigul J, et al. Chemical and biochemical changes of hybrid catfish fillet stored at $4^{\circ} \mathrm{C}$ and its gel properties. Food Chem. 2007; 103:420-27.

18. Abo-Zeid KSS. Chemical and histological studies on carp fish preserved at low temperature. M.Sc. Thesis. Fac of Agric. Cairo Univ. ARE. 1995.

19. Ozoğul F, Ozoğul Y. Determination of methods used for determination of total volatile basic nitrogen (TVB-N) in Rainbow Trout (Oncorhynchus mykiss). Turk J Zool. 2000;24:113-20.

20. Mahmoudzadeh M, Motallebi AA, Hosseini $H$, et al. Quality assessment of fish burgers from deep flounder (Pseudorhombus elevatus) and brushtooth lizardfish (Saurida undosquamis) during storage at $-18^{\circ} \mathrm{C}$. Iran J Fish Sci. 2010;9(1):111-26.

21. Dokuzlu C. The effect of acid-salt ratio used in the production of Marinated Anchovy to the microbiologic, organoleptic quality and determination of shelf-life of the product. J Pendik Vet Microbial. 1997;28(1):81-90.

22. Maga JA. Amines in Foods. Crit Rev Food Sci Nutr. 1978;373-403.

23. Yanar Y, Fenercioglu H. The utilization of carp (Cyprinus carpio) flesh as fish ball. Turk J Vet Anim Sci. 1999;23:36166.

24. Tokur B, Polat A, Beklevik G, et al. Changes in the quality of fish burger produced from Tilapia (Oreochromis niloticus) during frozen storage $(-18 \mathrm{C})$ Eur Food Res Technol. 2004;218:420-23.

25. Cadun A, Cakli S, Kisla D. A study of marination of deep water pink shrimp (Parapenaeus longirostris, Lucas, 1846) and its shelf life. Food Chem. 2005;90: 53-9.

26. Ibrahim SM, El-Sherif SA. Effect of some plant extracts on quality aspects of frozen Tilapia (Oreachromis niloticus L.). Glob Vet. 2008;2(2):62-6.

27. Orak HH, Kayisoglu S. Quality changes in whole, gutted and filletd three fish species (Gadus euxinus, Mugil cephalus, Engraulis encrasicholus) at frozen storage period $\left(-26^{\circ} \mathrm{C}\right)$. Acta Sci Pol Technol Aliment. 2008;7:15-28.

28. Ruiz-Capillas C, Moral A. Correlation between biochemical and sensory quality indices in hake stored in ice. Food Res Int. 2001;34:441-47.

29. Bilgin S, Cetinkaya S, Bolat Y. Changes on the nutritional compositions of the sand smelt (Atherina Boyeri Risso, 1810) marinade during storage. Afr J Biotechnol. 2011;1(15):2944-50.

30. Vareltzis K, Koufidis D, Gavriilidou E, et al. Effectiveness of a natural Rosemary (Rosmarinus officinalis) extract on thestability of filleted and minced fish duringfrozen storage. Eur Food Res Technol. 1997;205:93-6.

31. Suvanich V, Marshall DL, Jahncke ML. Microbiological and color quality changes of channel catfish framemince during chilled and frozen storage. J Food Sci. 2000;65:151-54. 
Citation: El-Lahamy AA, Khalil KI, El-Sherif SA, et al. Changes in quality attributes of sand smelt (Atherina hepsetus) fish burger and finger during frozen storage. J Fish Res. 2018;2(2):6-11.

32. Kose S, Boran M, Boran GK. Storage properties of refrigerated whitingmince after mincing by three different methods. Int J Food Sci Technol. 2006;42:887-93.

33. Ozyurt G, Polat A, Tokur B. Chemical and sensory changes in frozen $\left(-18^{\circ} \mathrm{C}\right)$ wild sea bass (Dicentrarchus labrax) captured at different fishing seasons. Int J Food Sci Technol. 2007;42:887-93.

\section{*Correspondence to:}

Adel A. El-Lahamy

National Institute of Oceanography and Fisheries

Fish Processing Technology Laboratory

Cairo

Egypt

E-mail: adelammar11@yahoo.com 